\title{
Survival and burden of cancer: A population-based analysis in a medium size city in
}

\section{Brazil}

\author{
Sobrevivência e carga do câncer: Uma análise baseada na população em uma cidade de tamanho \\ médio do Brasil
}

Supervivencia y carga de cáncer: Un análisis de población en una ciudad media de Brasil

Ione Jayce Ceola Schneider ORCID: https://orcid.org/0000-0001-6339-7832 Federal University of Santa Catarina, Brazil E-mail: ione.schneider@ufsc.br

Tauana Prestes Schmidt

ORCID: https://orcid.org/0000-0002-9055-0588 Federal University of Santa Catarina, Brazil E-mail: tauana.prestes@gmail.com

Paula Stefânia da Mota de Souza Patrício ORCID: https://orcid.org/0000-0002-2966-7111 Federal University of Santa Catarina, Brazil E-mail:paulafisiotcc@gmail.com

Rafael Aiello Bomfim

ORCID: https://orcid.org/0000-0002-6478-8664 Federal University of Mato Grosso do Sul, Brazil E-mail: aiello.rafael@gmail.com

Leandro Pereira Garcia ORCID: https://orcid.org/0000-0002-8601-7166 University of Southern Santa Catarina, Brazil E-mail: 1pgarcia18@gmail.com

Rodrigo Dias Nunes

ORCID: https://orcid.org/0000-0002-2261-8253 University of Southern Santa Catarina, Brazil E-mail: rodrigodiasnunes@hotmail.com

Eliane Traebert

ORCID: https://orcid.org/0000-0001-9667-7216 University of Southern Santa Catarina, Brazil E-mail: elisazevedot@gmail.com Jefferson Traebert

ORCID: https://orcid.org/0000-0002-7389-985X University of Southern Santa Catarina, Brazil E-mail: Jefferson.traebert@unisul.br

\begin{abstract}
Objective: The aim of this study was to estimate 5-year survival and the burden of cancer in a medium-sized city in Southern Brazil. Methods: A cohort study was performed using governmental data of incidence and mortality from cancer at Florianopolis/SC, Southern Brazil. Survival rates were performed using Kaplan Meier methods and log-rank test to compare curves. Disability-adjusted life years (DALY), years lived with disability (YLD) and years of life lost (YLL) and age-standardized rates of each indicator were estimated. Results: Thyroid, prostate and melanoma of skin had higher survival rates. Cancers presenting the highest burden, in decreasing order, were thyroid, prostate, breast, trachea, bronchus and lung, followed by colon and rectum. Conclusion: The estimates in local level could be help the health services to improve their quality. Highest burden was related to thyroid, prostate and breast due to the highest survival rates. Other cancer as trachea, bronchus and lung, and colon and rectum had high burden due to mortality.
\end{abstract} Keywords: Cancer; Disease burden; Mortality; Survival; Incidence; Epidemiology; Public health.

\section{Resumo}

Objetivo: Estimar a sobrevida em cinco anos e a carga de câncer em uma cidade de médio porte no sul do Brasil. Métodos: Foi realizado um estudo de coorte utilizando dados governamentais de incidência e mortalidade por câncer em Florianópolis/SC, Sul do Brasil. As taxas de sobrevivência foram realizadas usando os métodos Kaplan Meier e teste de log-rank para comparar as curvas. Anos de vida ajustados por incapacidade (DALY), anos vividos com incapacidade (YLD) e anos de vida perdidos (YLL) e taxas padronizadas por idade de cada indicador foram estimadas. Resultados: 
Tireoide, próstata e melanoma da pele tiveram maiores taxas de sobrevivência. Os cânceres que apresentaram maior carga, em ordem decrescente, foram tireoide, próstata, mama, traqueia, brônquios e pulmão, seguidos por cólon e reto. Conclusão: As estimativas em nível local podem ajudar os serviços de saúde a melhorar sua qualidade. A maior carga foi relacionada à tireoide, próstata e mama devido às maiores taxas de sobrevivência. Outros tipos de câncer, como traqueia, brônquios e pulmões, e cólon e reto, apresentaram alta carga devido à mortalidade.

Palavras-chave: Câncer; Carga de doença; Mortalidade; Sobrevivência; Incidência; Epidemiologia; Saúde pública.

\section{Resumen}

Objetivo: Estimar a sobrevida em cinco anos e a carga de câncer em uma cidade de médio porte no sul do Brasil. Métodos: Foi realizado um estudo de coorte utilizando datos de gobierno de incidência e mortalidade por cáncer en Florianópolis/SC, Sul do Brasil. As taxas de sobrevivência forram used using os métodos Kaplan Meier e teste de logrank para comparar as curvas. Anos de vida ajustados por incapacidade (DALY), anos vividos com incapacidade (YLD) e anos de vida perdidos (YLL) e taxas padronizadas por idade de cada indicador foram estimadas. Resultados: Tireoide, próstata e melanoma da pele tiveram maiores taxas de sobrevivência. Os cânceres que apresentaram maior carga, em ordem decrescente, foram tireoide, próstata, mama, traqueia, brônquios e pulmão, seguidos por cólon e reto. Conclusión: Como estimativas em nível local podem ajudar os serviços de saúde a melhorar sua qualidade. A maior carga foi relacionada à tireoide, próstata e mama devido às maiores taxas de sobrevivência. Outros tipos de câncer, como traqueia, brônquios e pulmões, e cólon e reto, apresentaram alta carga devido à mortalidade.

Palabras clave: Câncer; Carga de doença; Mortalidade; Sobrevivência; Incidência; Epidemiología; Saúde pública.

\section{Introduction}

Cancer is one of the major health problems worldwide. Cancer has taken higher position at the death's ranking, from third to second place in the last years, only behind cardiovascular diseases (Global Burden of Disease Cancer Collaboration et al., 2015). However, in high income and some upper-middle income countries, recent evidences have shown that deaths from cancer are common causes of deaths in middle age (35 to 70 years), and probably will become the leading cause of death in some years (Dagenais et al., 2019).

In 2008, 12,7 million cases of cancer were diagnosed worldwide. In 2013, that number increased to 14,9 million (Stewart \& Wild, 2014) and in 2018, up to 17,0 million new cancer cases were diagnosed (Bray et al., 2018). In Brazil, 600 thousand new cases were estimated in 2018 (Santos, 2018). If no global interventions are performed, it is expected that in the next two decades, mankind will have to deal with 25 million new cases of cancer annually (Stewart \& Wild, 2014).

The upward trend of cancer incidence, associated with other chronic diseases and population ageing is a great challenge, particularly for developing countries with insufficient equipment and not adequately organized health systems (Dagenais et al., 2019; Global Burden of Disease Cancer Collaboration et al., 2015; Santos, 2018; Stewart \& Wild, 2014).

The risk of occurrence and the type of cancer have marked differences between genders, social groups, nationalities, locations (Bray et al., 2018). Besides that, the survival after the diagnosis of cancer also is influenced by demographic (Zeng et al., 2015) and clinical factors (Parikh-Patel et al., 2017), socioeconomical level (Tervonen et al., 2017) and also by the health system coverage (Ellis et al., 2018; Niu et al., 2013; Parikh-Patel et al., 2017). Data about cancer varies in quantity and quality, from complete population-based records to the almost complete lack of information, depending on the region (Stewart \& Wild, 2014).

The adequate management of cancer depends on the existence of information systems, allowing the understanding of its occurrence. Before 1990, there were no clear and internally consistent data sources on the global burden of diseases, injuries, and risk factors. To address this shortfall, the World Bank and the World Health Organization (WHO) launched the Global Burden Disease Study (GBD). GBD uses comparable methods to analyze available information for diseases and injuries that are comparable by using standardized metrics (Murray, 1994; Christopher Murray \& Lopez, 2013). Disability-Adjusted Life Year (DALY) is the proposed basic measure of overall burden of disease. One DALY represents one lost year of healthy life. This health indicator condenses morbidity and mortality into a single measure (Murray \& Lopes, 1996). 
On the other hand, data on cancer survival, morbidity and mortality at national level may not reflect the local reality of different communities of a same country. In Brazil, this is particularly important since the demographic and epidemiological changes have not been experienced uniformly across states. There are subnational disparities in health indicators and different health systems priorities (GBD 2016 Brazil Collaborators, 2018). The allocation of resources to local health systems to cope with cancer could be completely inadequate, if it would be based on the mean rates of a larger area, such as national-based indicators. In this way, the adaptation and using the GBD method can be useful and should present better results comparing to national-based measures. The present study aimed to estimate the survival and burden of cancer in a high-income city in Southern Brazil for improving the National Cancer Control Planning.

\section{Methodology}

A cohort study was performed to estimate the survival and burden of cancer in the city of Florianópolis, Brazil, in 2008. Florianópolis, the state capital of Santa Catarina, is an island located off the Southern Brazilian coast. In 2015, its population was estimated at 469,690 inhabitants (Instituto Brasileiro de Geografia e Estatística, 2019). The municipal Human Development Index was 0.847 in 2010, ranking third among Brazilian municipalities and the first among Brazilian state capitals (Brasil, 2013).

All registers from the Population-based Cancer Registry (RCBP - Registro de Câncer de Base Populacional) of residents in 2008 were included. RCBP is a systematized information system for collection, storage and analysis of the occurrence and characteristics of new cases of cancer at municipal level (Ministério da Saúde, 2012). Florianópolis is one of the 23 Brazilian cities with this kind of records (Ministério da Saúde, 2019). Data from deaths attributed to cancer, registered in the Brazilian Mortality Information System (SIM - Sistema de Informação sobre Mortalidade) (Ministério da Saúde, 2017) was also included, from the same year. For that purpose, the term "neoplasm", at the International Disease Code (ICD-10) was used to research cases (Organização Mundial da Saúde, 1997).

The collected information was classified by type of cancer according to Soerjomataram (Soerjomataram, LortetTieulent, Ferlay, et al., 2012; Soerjomataram, Lortet-Tieulent, Parkin, et al., 2012) stratified by age and gender. Non-melanoma skin cancer was excluded, because data usually does not reflect reality, due to the high incidence and register difficulties. Kaposi's sarcoma was also excluded, because it is derived from the human immunodeficiency virus (HIV).

The RCBP allowed to identify the date and cause of death, cross-checked to obtain time of living with the diagnosis. People who emigrated from Florianópolis, between 2008 and 2013 were searched. Cross-checking RCBP and SIM databases was based on a probabilistic record linkage method, in which the user designates the association rules between two tables, using the OpenRecLink software (Kenneth R. de Camargo Jr. \& Coeli, 2000; Kenneth Rochel de Camargo Jr. \& Coeli, 2015; Coutinho $\&$ Coeli, 2006). The RCBP variables were registration number, name, date of birth, and mother's name. SIM variables were used to pair data, such as death certificate number, name, date of birth, mother's name, date of death, cause of death, and city of residence. After merging records, a new database was created allowing to proceed the data analysis. Survival time was calculated as the interval between the date of diagnosis and the date of death or the end of follow-up. The maximum follow-up period was five years, and those who were not located on SIM were considered alive. The date of censorship was the end of the follow-up period.

Overall survival curves estimated the median survival time by the Kaplan-Meier method. The analyses according to cancer type were stratified by gender and log-rank test was performed to estimate the difference between the curves. Stata Statistical software SE 14.0 for survival analysis was used.

To estimate the burden of cancer, DALY was estimated by the sum of the Years Lived with Disability (YLD) and the Years of Life Lost (YLL). YLD is the result of the burden of the disease, expressed by a standard weight multiplied by the cases duration, using incident cases. The weights used were based on the Global Burden of Disease Study (GBD) (C. J L Murray, 
1994; Christopher J L Murray et al., 2012; Soerjomataram, Lortet-Tieulent, Ferlay, et al., 2012; Soerjomataram, Lortet-Tieulent, Parkin, et al., 2012) and stratified according to the following categories: a) diagnosis and initial treatment; b) control; c) preterminal; d) terminal. The "terminal" stage was used if it took less than 60 days between diagnosis and death (Llobera et al., 2000). All other cases were included as "diagnosis and initial treatment".

Duration was based in survival analysis. When estimation of the median survival time from the survival curves was not possible due to the low number of deaths, a Microsoft Excel 2007 spreadsheet was created for estimation of probabilities for each month during the follow-up period. Based on this spreadsheet, a trend line in a linear regression model was created (Dupont, 2009). The time when the probability of survival was 50\% (median time) was estimated. When it was not possible to estimate the median time (for melanoma, thyroid cancer and prostate cancer), duration of the disease was defined as the life expectancy.

YLL was estimated between the difference of death age and the standardized life expectancy, which was set at 86 years, according to GBD (Christopher J L Murray et al., 2012; Soerjomataram, Lortet-Tieulent, Ferlay, et al., 2012).

DALY, YLL and YLD indicators were estimated by gender, age and disease types. To obtain adjusted rates per 100,000 population, specific rates by age, gender and disease type were calculated, which were later standardized by using the direct method. The standard world population was used as reference (Cancer Incid. Five Cont, 1966).

This study was approved by the Research Ethics Committee of the Universidade do Sul de Santa Catarina under CAAE 30834414.5.0000.5369. It is based on ethical principles, according to Resolution no. 466, December 12th, 2012, of the Brazilian National Health Council.

\section{Results}

During the year 2008 1,339 new cancer diagnosis and 432 deaths were reported in Florianópolis. Table 1 presents the incidence and death frequencies, survival rate at 24 e 60 months after the diagnosis, and the duration of disease. Thyroid (15.8\%), breast $(12.8 \%)$ and prostate $(11.0 \%)$ were the most incident cancers. Deaths by cancer were more frequent related to trachea, bronchus, and lung (16.0\%), colon and rectum (10.4\%) and stomach $(9.5 \%)$ cancers. The best 5 -year-survival rates were found in thyroid $(98.6 \%)$, testis $(83.7 \%)$ and melanoma $(83.7 \%)$ cancers. The worst 5-year-survival rates were found in other pharynx $(18.8 \%)$, trachea, bronchus and lug $(22.5 \%)$ and pancreas $(23.1 \%)$ cancers a. No difference was found in survival rates when it was estimated by gender (Log-rank test $>0.05$ ) (data not shown). 
Table 1. Cancer types, frequencies, weights, and duration used to calculate the YLD. Florianópolis/SC, Brazil.

\begin{tabular}{|c|c|c|c|c|c|}
\hline \multirow{2}{*}{ Cancer Types } & \multirow{2}{*}{$\begin{array}{c}\text { Incidence } \\
\mathbf{n}(\%) \\
\end{array}$} & \multirow{2}{*}{$\begin{array}{l}\text { Deaths } \\
\text { n }(\%) \\
\end{array}$} & \multicolumn{2}{|c|}{ Survival rate $(95 \% \mathrm{CI})$} & \multirow{2}{*}{$\begin{array}{c}\text { Duration } \\
\text { (years) }\end{array}$} \\
\hline & & & 24 months & 60 months & \\
\hline Lip and oral cavity (C00-C08) & $25(1.9)$ & $11(2.5)$ & $64.0(42.2-79.4)$ & $56.0(34.8-72.7)$ & $5.36 \dagger$ \\
\hline Nasopharynx (C11) & $5(0.4)$ & $3(0.7)$ & $60.0(12.6-88.2)$ & $40.0(5.2-75.3)$ & 3.69 \\
\hline Other pharynx (C09-10, C12-14) & $16(1.2)$ & $12(2.8)$ & $43.8(19.8-65.6)$ & $18.8(4.6-40.3)$ & 1.61 \\
\hline Esophagus (C15) & $21(1.6)$ & $12(2.8)$ & $61.9(38.1-78.8)$ & $42.9(21.9-62.3)$ & 2.98 \\
\hline Stomach $(\mathrm{C} 16)$ & $67(5.0)$ & $41(9.5)$ & $50.8(38.1-62.1)$ & $36.9(25.4-48.5)$ & 2.03 \\
\hline Colon and rectum $(\mathrm{C} 18-21)$ & $129(9.6)$ & $45(10.4)$ & $73.6(65.1-80.4)$ & $65.1(56.2-72.6)$ & $8.10 \dagger$ \\
\hline Liver (C22) & $25(1.9)$ & $18(4.2)$ & $32.0(15.2-50.2)$ & $28.0(12.4-46.0)$ & 0.50 \\
\hline Gallbladder (C23-24) & $9(0.7)$ & $6(1.4)$ & $50.0(15.2-77.5)$ & $37.5(8.7-67.4)$ & 1.67 \\
\hline Pancreas (C25) & $14(1.0)$ & $11(2.5)$ & $23.1(5.6-47.5)$ & $23.1(5.6-47.5)$ & 0.69 \\
\hline Larynx (C32) & $13(1.0)$ & $8(1.9)$ & $58.3(27.0-80.1)$ & $41.7(15.3-66.5)$ & 2.62 \\
\hline Trachea, bronchus and lung (C33-34) & $90(6.7)$ & $69(16.0)$ & $33.7(24.1-43.5)$ & $22.5(14.5-31.6)$ & 0.98 \\
\hline Melanoma of skin (C43) & $49(3.7)$ & $8(1.9)$ & $87.8(74.8-94.3)$ & $83.7(70.0-91.5)$ & $\begin{array}{c}\text { Life } \\
\text { expectancy }\end{array}$ \\
\hline Breast (C50) & $171(12.8)$ & $38(8.8)$ & $94.2(89.4-96.8)$ & $77.8(70.8-83.3)$ & $11.38 \dagger$ \\
\hline Cervical uteri (C53) & $36(2.7)$ & $11(2.5)$ & $83.3(66.6-92.1)$ & $69.4(51.7-81.8)$ & $7.92 \dagger$ \\
\hline Corpus uteri (C54) & $15(1.1)$ & $5(1.2)$ & $86.7(56.4-96.5)$ & $66.7(37.5-84.6)$ & $8.21 \dagger$ \\
\hline Ovary (C56) & $15(1.1)$ & $6(1.4)$ & $73.3(43.6-89.1)$ & $60.0(31.8-79.7)$ & $5.80 \dagger$ \\
\hline Prostate (C61) & $147(11.0)$ & $23(5.3)$ & $91.2(85.3-94.8)$ & $84.4(77.4-89.3)$ & $\begin{array}{c}\text { Life } \\
\text { expectancy }\end{array}$ \\
\hline Testis (C62) & $10(0.7)$ & $1(0.2)$ & $90.0(47.3-98.5)$ & $90.0(47.3-98.5)$ & $4.05 \dagger$ \\
\hline Kidney (C64-66) & $35(2.6)$ & $8(1.9)$ & $91.2(75.1-97.1)$ & $79.4(61.6-89.6)$ & $14.96 \dagger$ \\
\hline Bladder (C67) & $58(4.3)$ & $17(3.9)$ & $81.0(68.4-89.0)$ & $70.7(57.2-80.6)$ & $11.14 \dagger$ \\
\hline $\begin{array}{l}\text { Brain and central nervous system } \\
(\mathrm{C} 70-72)\end{array}$ & $18(1.3)$ & $10(2.3)$ & $55.6(30.5-74.8)$ & $44.4(21.6-65.1)$ & 3.44 \\
\hline Thyroid (C73) & $211(15.8)$ & $3(0.7)$ & $99.1(96.3-99.8)$ & $98.6(95.7-99.5)$ & $\begin{array}{c}\text { Life } \\
\text { expectancy }\end{array}$ \\
\hline Hodgkin lymphoma (C81) & $5(0.4)$ & $2(0.5)$ & $80.0(20.4-96.9)$ & $60.0(12.6-88.2)$ & $5.83 \dagger$ \\
\hline $\begin{array}{l}\text { Non-Hodgkin lymphoma (C82-85, } \\
\text { C96) }\end{array}$ & $50(3.7)$ & $18(4.2)$ & $70.0(55.3-80.7)$ & $64.0(49.1-75.6)$ & $8.33 \dagger$ \\
\hline Multiple myeloma (C88, C90) & $13(1.0)$ & $7(1.6)$ & $76.9(44.2-91.9)$ & $46.2(19.2-69.6)$ & $5.93 \dagger$ \\
\hline Leukemia (C91-95) & $32(2.4)$ & $14(3.2)$ & $62.5(43.5-76.7)$ & $56.3(37.6-71.3)$ & $5.74 \dagger$ \\
\hline Others* & $60(4.5)$ & $25(5.8)$ & $68.3(55.0-78.5)$ & $53.3(40.0-65.0)$ & $5.00 \dagger$ \\
\hline Total & $1,332(100.0)$ & $432(100.0)$ & & & \\
\hline
\end{tabular}

* Others: C17, C26, C30, C38, C40, C41, C48, C49, C51, C55, C57, C60, C69, C74, C76, C80.

$\uparrow$ Estimated duration.

Source: Authors.

In 2008, all studied cancers were responsible for 15,331.7 DALYs in Florianópolis, representing 3,530.3 DALYs per 100,000 inhabitants. YLL was responsible for 56.9\% of DALY. The relative contribution for DALYs varied according to type of cancer. Thyroid, prostate and breast cancers showed greater values of DALY and YLD, while trachea, bronchus and lung, colon and rectum and breast cancers, for YLL. The distribution of DALYs and their components according to the type of cancers are showed in Table 2. 
Table 2. Disability-Adjusted Life Years (DALY), Years of Life Lost (YLL) and Years Lived with Disability (YLD) and their standardized rates per 100,000 inhabitants according to cancer types. Florianópolis/SC, Brazil.

\begin{tabular}{lcccccc}
\hline \multirow{2}{*}{ Cancer types } & \multicolumn{2}{c}{ YLD } & \multicolumn{2}{c}{ YLL } & \multicolumn{2}{c}{ DALY } \\
\cline { 2 - 7 } & $\mathbf{n}$ & Rate* & $\mathbf{n}$ & Rate* & n & Rate* $^{*}$ \\
\hline Lip and oral cavity (C00-C08) & 69.27 & 15.62 & 175 & 38.31 & 244.27 & 53.94 \\
Nasopharynx (C11) & 10.32 & 2.50 & 48 & 11.27 & 58.32 & 13.77 \\
Other pharynx (C09-10, C12-14) & 13.65 & 3.33 & 91 & 20.31 & 104.65 & 23.64 \\
Esophagus (C15) & 28.48 & 6.76 & 208 & 48.66 & 236.48 & 55.43 \\
Stomach (C16) & 56.68 & 13.25 & 437 & 104.88 & 493.68 & 118.13 \\
Colon and rectum (C18-21) & 383.95 & 91.45 & 726 & 176.26 & $1,109.95$ & 267.70 \\
Liver (C22) & 4.71 & 1.11 & 415 & 95.78 & 419.71 & 96.89 \\
Gallbladder (C23-24) & 5.74 & 1.35 & 58 & 13.10 & 63.74 & 14.45 \\
Pancreas (C25) & 3.44 & 0.78 & 435 & 102.75 & 438.44 & 103.54 \\
Larynx (C32) & 14.80 & 3.26 & 109 & 25.56 & 123.80 & 28.82 \\
Trachea, bronchus and lung (C33-34) & 54.07 & 12.93 & 1,493 & 346.08 & $1,547.07$ & 359.01 \\
Melanoma of skin (C43) & 425.68 & 92.98 & 309 & 64.05 & 734.68 & 157.03 \\
Breast (C50) & 994.96 & 221.40 & 595 & 138.27 & $1,589.96$ & 359.67 \\
Cervical uteri (C53) & 115.77 & 24.34 & 145 & 33.14 & 260.77 & 57.49 \\
Corpus uteri (C54) & 47.50 & 10.87 & 40 & 12.21 & 87.50 & 23.08 \\
Ovary (C56) & 37.39 & 8.41 & 222 & 52.21 & 259.39 & 60.61 \\
Prostate (C61) & $1,506.39$ & 376.20 & 158 & 42.53 & $1,664.39$ & 418.73 \\
Testis (C62) & 10.94 & 2.06 & 51 & 10.05 & 61.94 & 12.11 \\
Kidney (C64-66) & 127.71 & 31.98 & 182 & 45.31 & 309.71 & 77.29 \\
Bladder (C67) & 145.05 & 36.17 & 152 & 34.84 & 297.05 & 71.01 \\
Brain and central nervous system (C70-72) & 42.16 & 10.31 & 376 & 84.70 & 418.16 & 95.01 \\
Thyroid (C73) & $2,226.42$ & 465.19 & 37 & 10.02 & $2,263.42$ & 475.21 \\
Hodgkin lymphoma (C81) & 16.02 & 3.16 & 60 & 12.42 & 76.02 & 15.57 \\
Non-Hodgkin lymphoma (C82-85, C96) & 195.87 & 43.46 & 470 & 95.16 & 665.87 & 138.62 \\
Multiple myeloma (C88, C90) & 11.40 & 2.89 & 94 & 21.74 & 105.40 & 24.63 \\
Leukemia (C91-95) & 83.84 & 22.13 & 343 & 99.38 & 426.84 & 121.52 \\
Others & 40.16 & 8.82 & 1,185 & 269.86 & $1,225.16$ & 278.68 \\
\hline
\end{tabular}

*Rate per 100,000 inhabitants. Source: Authors.

In relation to the gender, $50.1 \%$ (3,559.5 per 100,000 inhabitants) were observed in men and 49.9\% (3,553.3 per 100,000 inhabitants) in women. The highest DALY rates observed in women were thyroid cancer (772.6 per 100,000 women), breast cancer (663.7 per 100,000 women) and trachea, bronchus, and lung cancers (321.7 per 100,000 women). The mortality component was higher in almost all types except thyroid, breast, and melanoma cancers in women (Figure 1). Among men, the highest rates of DALY were found in prostate (940.3 per 100,000 men), trachea, bronchus and lung (410.1 per 100,000 men) and colon and rectum cancers (243.6 per 100,000 men). The mortality component was greater in all cases, with the exceptions of the prostate, thyroid and melanoma cancers (Figure 2). 
Figure 1. Standardized DALY rates (per 100,000 inhabitants) and their mortality (YLL) and disability (YLD) components, according to cancer types in women. Florianópolis/SC, Brazil.

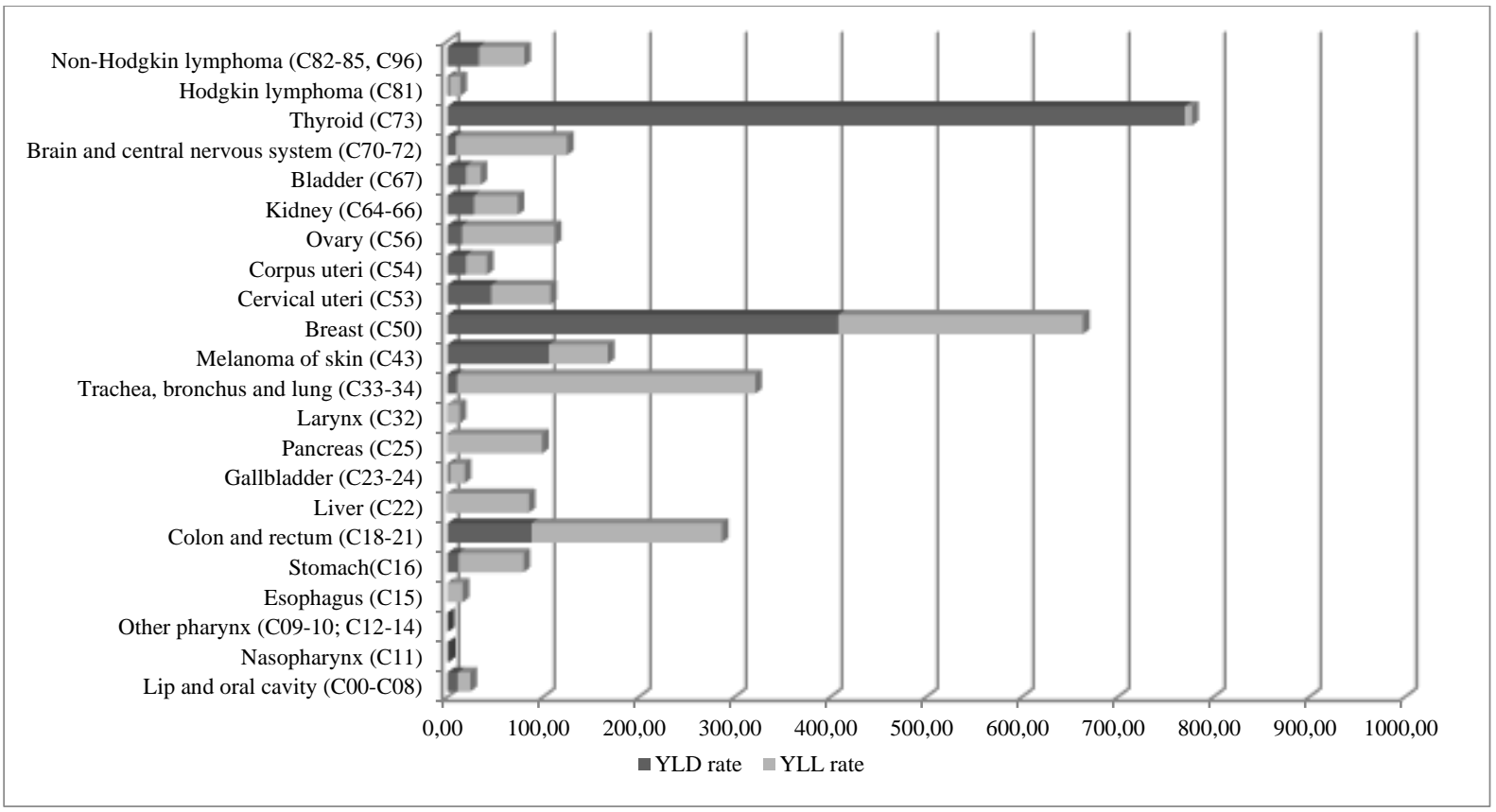

Source: Authors.

Figure 2. Standardized DALY rates (per 100,000 inhabitants) and their mortality (YLL) and disability (YLD) components, according to cancer types in men. Florianópolis/SC, Brazil.

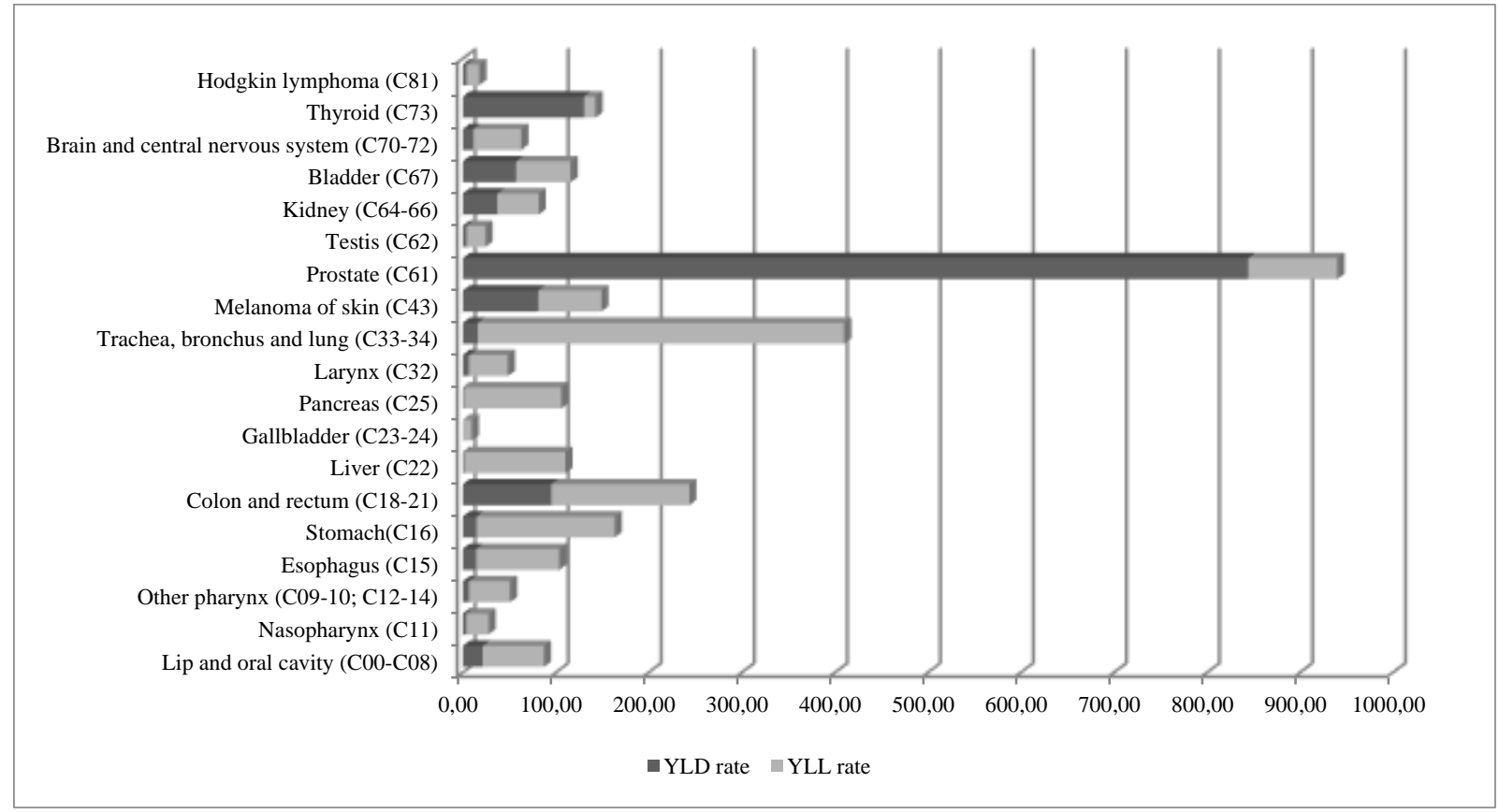

Source: Authors.

According to age, the highest rates were found in groups of 60 to 64 years (521.4 per 100,000 inhabitants), 65 to 69 years (484.4 per 100,000 inhabitants), and 50 to 54 years (464.8 per 100,000 inhabitants), respectively. The rates distribution by age differed by gender. Women have higher rates in age group of 40 to 45 years, while in men, these rates were higher in those from 60 to 69 years (Figure 3). 
Research, Society and Development, v. 10, n. 5, e40210515140, 2021

(CC BY 4.0) | ISSN 2525-3409 | DOI: http://dx.doi.org/10.33448/rsd-v10i5.15140

Figure 3. Standardized DALY rates (100,000 inhabitants) and their mortality (YLL) and disability (YLD) components due to cancer, according to age, globally (A), in women (B) and in men (C). Florianópolis/SC, Brazil.

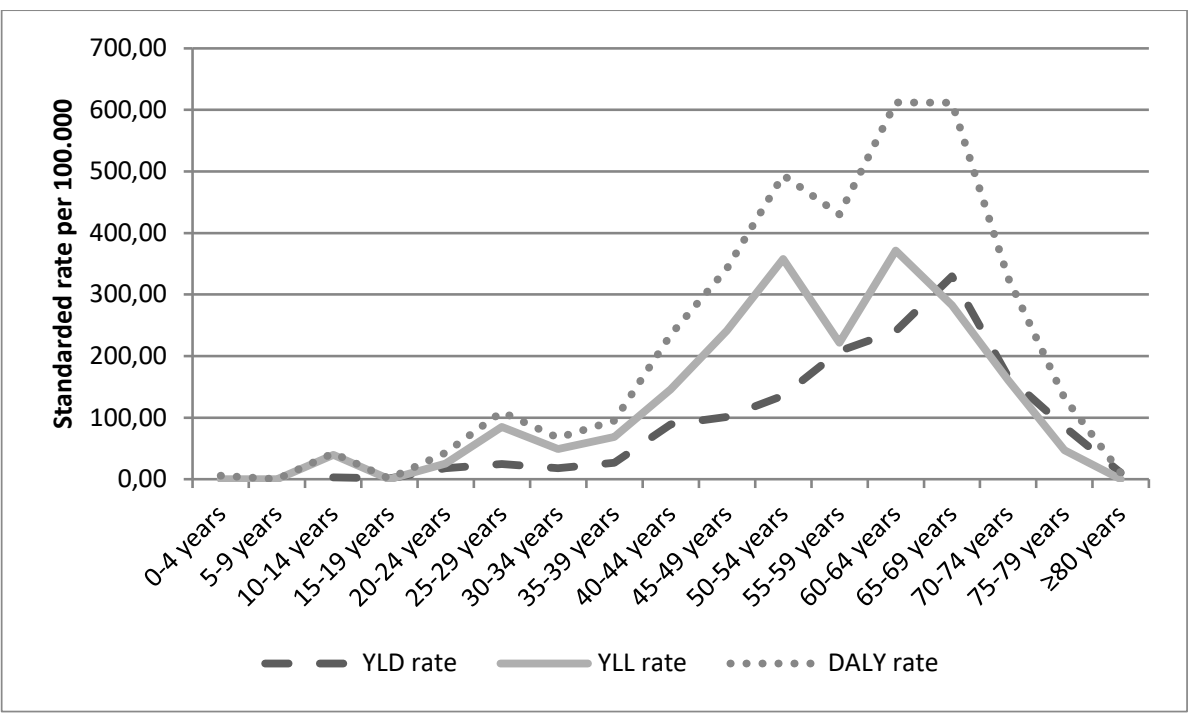

A

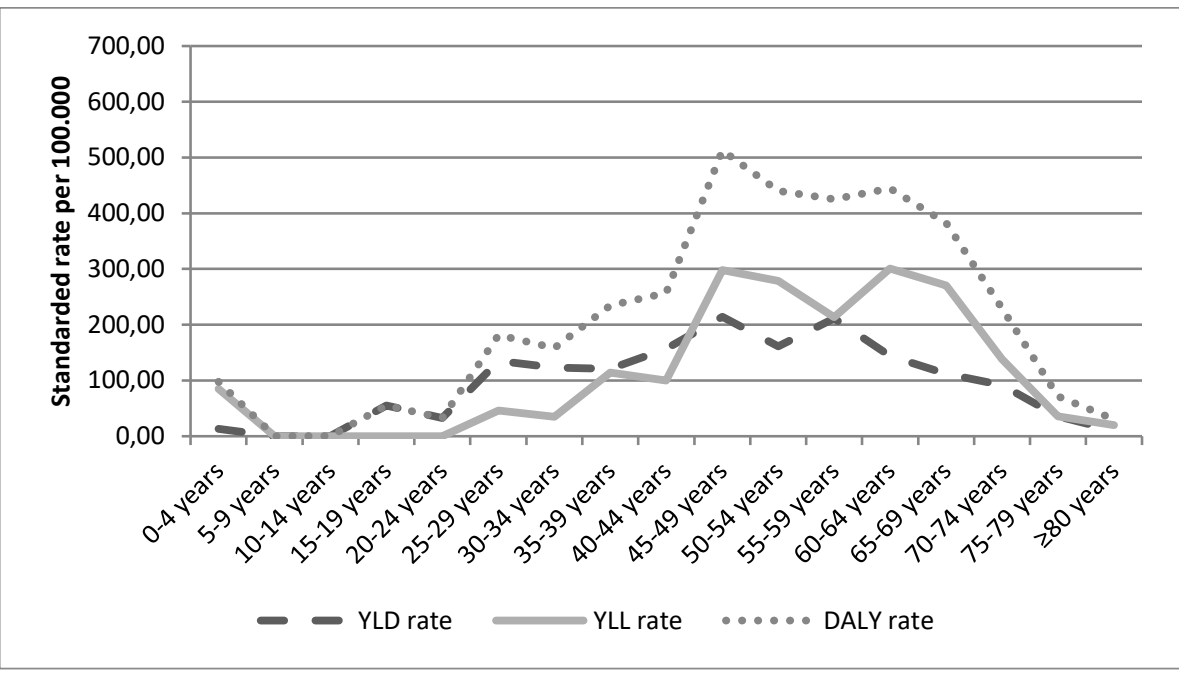

B

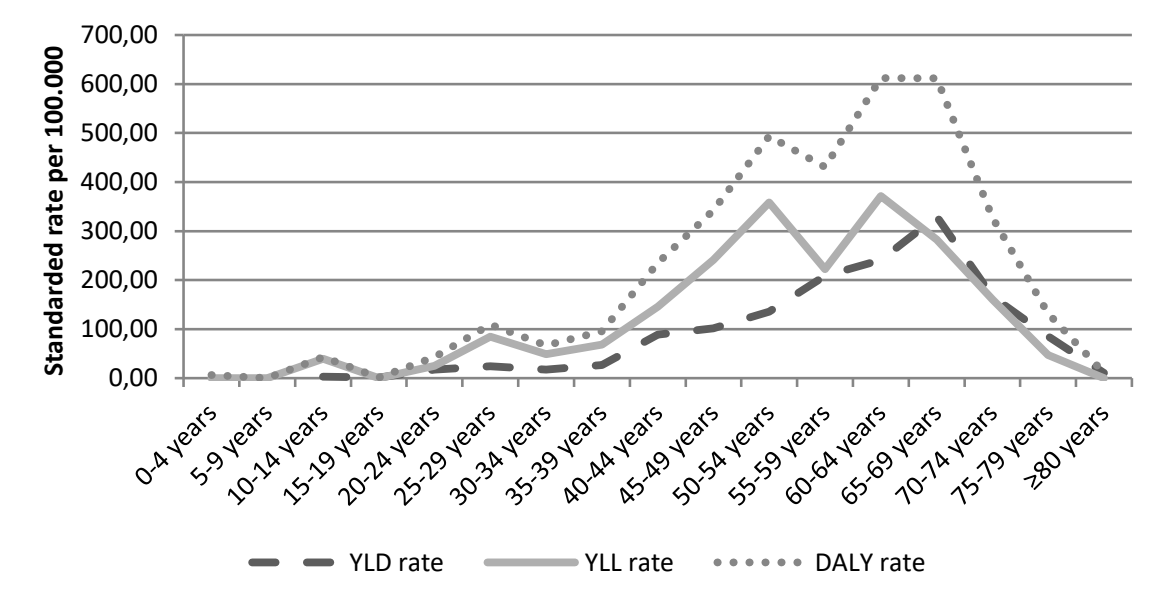

C 


\section{Discussion}

Our results showed three important findings. First, thyroid, breast and prostate cancer showed the highest burden due to higher incidence. Second, trachea, bronchus and lung (C33-C34) and colon and rectum (C18-21) showed the highest burden due to deaths. Third, National Cancer Control Plans should incorporate local level analysis, especially because of high health inequalities in a continental country such as Brazil.

Cities context should be considered in the analysis on burden of disease. The GBD showed that the top ranked cancers by absolute deaths were prostate for males and breast cancer for females (Global Burden of Disease Cancer Collaboration et al., 2019). However, in Florianópolis, trachea, bronchus and lung (16\%) followed by colon and rectum (10.4\%) were the top ranked cancers by absolute deaths, differing from the Brazilian top ranked at GBD 2019, showing the importance of local level analysis for resources allocation, health planning strategies and implementation research for preventing new cases.

National Cancer Control Plans are an important tool for planning resources allocation and services planning, especially in a continental country like Brazil (Strasser-Weippl et al., 2015). Funding for health care has been reduced dramatically in Family Health Strategy with the freezing in health expenditure (Constitutional Amendment Number, 2016) in the Unified Health System (SUS). Funds, insurance coverage, doctors, health-care workers, resources, and equipment were also very inequitably distributed between and within the main regions of Brazil. Scarcity of cancer registries and analysis at local level, including initiatives for primary prevention is surely necessary as demonstrated by this study (Strasser-Weippl et al., 2015).

Thyroid cancer accounted for the highest burden due to cancer in this study. Thyroid cancer incidence increased $95 \%$ from 1990 to 2013 (Global Burden of Disease Cancer Collaboration et al., 2015). In the 2019 GBD, thyroid was at 28 position with no change in YLL. In this study thyroid cancer accounted 475,21 DALYs per 100,000 inhabitants and the survival rate was higher than $95 \%$. One reason for this favourable prognosis is the early detection (Chirlaque et al., 2018). However, many cases may have been classified as follicular encapsulated variant of papillary thyroid carcinoma. Because of its low risk of invasiveness, most of these tumours have been reclassified as non-invasive, reducing its burden (Nikiforov et al., 2016).

GBD 2019 showed that prostate cancer increased one position in the YLL (12th to 11th position) with a change of $28 \%$. In 2017, there were 1.3 million incident cases and 416,000 deaths, generating 7.1 million DALYs, with 88\% from YLL and 12\% from YLD (Global Burden of Disease Cancer Collaboration et al., 2019). Prostate cancer accounted for the second highest burden in this study with 418,73 DALYs per 100,000 inhabitants with a 5-year-survival rate of $84.4 \%$. Furthermore, 9\% reduction was reported in the prostate cancer burden in developed countries and 27\% increase in developing countries like Brazil. However, a global reduction in its burden related to YLL was reported (Global Burden of Disease Cancer Collaboration et al., 2015). In Brazil, age-standardized prostate cancer mortality rates increased since 1980 (Tourinho-Barbosa et al., n.d.), although not expressively (Guerra et al., 2017). After 2006, trends towards stabilization was observed (Tourinho-Barbosa et al., n.d.) but the absolute number of deaths have been raised (Jerez-Roig et al., 2014). This increased risk of death is related to aging process in recent decades in Brazil (Tourinho-Barbosa et al., n.d.).

Breast cancer accounted for the third highest burden in this study. GBD 2019 showed that it was the third most incident cancer with 2 million-incident cases in 2017. It generated 17.7 million DALYs for both sexes, coming 93\% from YLL and 7\% YLD. Globally, 1 in 18 women develop breast cancer over a lifetime. In Brazil, the burden of YLL changed the 31 position in 1990, to 16 position in 2016 (GBD Brazil Collaborators, 2018). In Florianópolis it is one of highest YLL rate with 138.27 per 100,000 inhabitants. In women, breast cancer presents highest rates of mortality. The rate was stable between 1990 to 2015 , around 16.4 per 100,000 women. This stability was observed across the Brazilian states (Guerra et al., 2017). 5-year-survival rate observed in this study was similar to the rate in Spain $(78,9 \%)$ (Chirlaque et al., 2018). Middle age group experienced the highest survival rates (Niu et al., 2013) but considering all age groups, improvement in survival rates was observed (Zeng et al., 2015). 
Trachea, bronchus and lung cancer accounted for the fourth highest burden in this study. Lung cancer is an emergent disease in women and it is known as a very aggressive disease (Chirlaque et al., 2018). Survival rates found in this study was higher than those found in Spain (Chirlaque et al., 2018) and similar than those estimated to Brazil in 2005-2009 (Cheng et al., 2016) but higher than those estimated to 2000-2014 (Allemani et al., 2018). Between 1990 and 2009, all age groups have improved the survival rates in the USA but the improvement was higher in younger ages (Zeng et al., 2015). No difference was found between gender, but usually, women have better survival rates (Cheng et al., 2016; Chirlaque et al., 2018; Niu et al., 2013). The low survival rates in lung cancer patients is attributed to advanced stage at diagnosis. In Brazil differences within regions have been observed, even though adjusted by stage at diagnosis. The reason for this difference is not clear (Cheng et al., 2016). Lung cancer is the second leading cause of death among man and women in the 1990-2015 period, but it has decreased in men and it has increased in women (Guerra et al., 2017; José et al., 2017). Both in developed and developing countries, this type of cancer presents the highest death rate, as well as the highest YLL, confirmed by our findings. Furthermore, there was a burden reduction, which may be attributed to the efforts to prevent and reduce smoking (Global Burden of Disease Cancer Collaboration et al., 2015). This cancer had caused 36.4 thousand DALYs in the world in 2016, and the YLL component was responsible for $99 \%$ of them (Global Burden of Disease Cancer Collaboration et al., 2018). It was the 27th cause in the ranking of DALYs (GBD 2017 DALYs and HALE Collaborators, 2018). According to the gender, it is the seventh in women and the first in men. Tobacco use and air pollution were the leading risk factors for lung cancer in India in 2016 to which $43.2 \%$ and 43,0\% of the lung cancer DALYs could be attributed (India State-Level Disease Burden Initiative Cancer Collaborators, 2018). In Brazil, YLL due to lung cancer decreased between 1990 and 2016, but this disease raised from 20 to 13 position the most important cause of YLL (GBD Brazil Collaborators, 2018). 1.3\% of cancer-related DALYs was attributable to smoking as a cause of premature mortality and disability and $2.3 \%$ of deaths due to lung cancer (José et al., 2017). In our study, YLL due to this type of cancer reached the higher burden with 346.08 DALYs per 100,000 inhabitants. Strategies to improve the tobacco control and the air and environmental quality are needed as primary prevention interventions (Cheng et al., 2016) and need to be encouraged in National Cancer Control Plans. In Santa Catarina, this cause was responsible for 334.8 DALYs for 100,000 inhabitants (Traebert et al., 2013), similar values observed in our study.

GBD 2019 showed 1.8 million incident cases and 896,000 deaths due to colon and rectum cancer. It generated 19 million DALYs, which 95\% related to YLL, and 5\% to YLD. In New Jersey (USA), women had a survival advantage over men for colorectal cancer (Niu et al., 2013), but this difference was not observed in Spain (Chirlaque et al., 2018) as well as in the present study. We observed survival rates higher than those in Spain (Chirlaque et al., 2018). Besides that, improvements of the survival rates especially in young ages were shown in the USA (Zeng et al., 2015). Mortality rates from this cancer have improved in male and showed to be stable in women in the period from 1990 to 2015 in Brazil. But in the South and Southeast states higher rates were reported (Guerra et al., 2017). Colon and rectum cancer was in 39th position in YLL causes in 1990, and raised to 19th position in 2016 (GBD Brazil Collaborators, 2018). In 2013, cancer of the colon and rectum caused 15.8 million DALYs worldwide, with a rate of 346.7 DALYs per 100,000 people, similar to what was found in this study. Men present higher risk to develop this cancer, and its burden is higher in developed as compared to developing countries (Global Burden of Disease Cancer Collaboration et al., 2015). In 2016, this cancer was responsible for 17.2 million, of which 97\% came from YLLs (Global Burden of Disease Cancer Collaboration et al., 2018). In the period of 2007 to 2017, the number of DALY due to colon and rectum cancer increased $24.5 \%$, but the rate dropped $6.0 \%$, greater in women (GBD DALYs and HALE Collaborators, 2018). The risk of occurrence of colon and rectum cancer has been associated with the consumption of red meat. The number of DALYs increases proportionally to the quantity of red meat consumed for all ages (De Oliveira Mota et al., 2019).

We have to point out some considerations. The increase in incidence of cancer and other chronic diseases, associated with the population ageing, has been a serious threat particularly to developing countries, like Brazil. These countries accumulate 
about $86 \%$ of the burden of these diseases due to premature deaths, besides the limitations in their health systems to deal with the problem (Global Burden of Disease Cancer Collaboration et al., 2015; Stewart \& Wild, 2014). Measuring the local disease burden, as proposed here may help to rationalize activities of local health systems, in order to enable better allocation of resources, greater effectiveness of interventions and a reduction of risks and damages. Estimation of DALY at local level helps to determine the magnitude, transcendence and vulnerability of injuries and diseases (Pereira, 2011; Teixeira, 2010). In this way, determining the problem's extension can contribute to choose better health planning models and to set priorities for investment, especially because Brazilian amendment constitutional number 95/2016 that freeze public expenditures on health, need a strategy for improving National Cancer Control Plans.

As strengths of the study, we should mention that the estimative of survival data was obtained from a cancer populationbased registry. Thus, the results will be applicable to the general population and. This analysis has shown to be feasible for implementation at local level. The existence of structured databases with information on population-based cancer registries made it possible. Another strength is related to the use of real data, rather than modelled data such as used by the GBD in several times. Higher rates may be related to the fact that the number of incident cases recorded by the RCBP of Florianópolis in 2008 was greater than the number of incident cases estimated for that year (Brasil., n.d.). Additionally, the estimated survival rates were also high what have influenced directly in the YLD rates. However, the existence of structured databases to estimate the survival and burden due to cancer does not guarantee the existence of all necessary information. On the other hand, a limitation of this study was related to the absence of data to staging and monitoring cancer cases, especially in relation to the control of disease. We cannot guarantee that all people who dyed was found when we performed the record linkage of dataset used to find the death date. Therefore, cancer had to be classified in only two categories for weight assignment, which may have resulted in underestimation or overestimation of the burden of disease, since other clinical situations with different weights have not been considered.

Among the various orientations of the Brazilian Ministry of Health focused on the organization of the health system in relation to cancer control, two of them deserve special mention. First, the National Cancer Prevention and Control Policy in the Health Care Network of People with Chronic Diseases in the scope of SUS, instituted by Ordinance No. 874, of May 16, 2013. And in second, the document that redefines the criteria and rules for the organization, planning, monitoring, control and evaluation of health practices enabled in specific care in oncology and definition, as defined in Resolution No. 140, February 27, 2014. Despite the freezing health expenditure by Constitutional amendment number 95/2016, Brazilian National Cancer Control Plans should not be restricted to breast cancer, tobacco control and cervical and uterine cancer.

\section{Conclusion}

The highest burden was related to thyroid, prostate and breast due to the highest survival rates. Other cancer such as trachea, bronchus and lung, and colon and rectum had high burden due to mortality. It is necessary to upstream policies, resources allocation and health system planning to deal with great heterogeneities in Brazil. Improving strategies for primary cancer prevention, especially controlling overweight and obesity, and consume of red meat is mandatory, because the important role as a common risk factor for breast and colom and rectum cancers.

\section{References}

Allemani, C., Matsuda, T., Di Carlo, V., Harewood, R., Matz, M., Nikšić, M., Bonaventure, A., Valkov, M., Johnson, C. J., Estève, J., Ogunbiyi, O. J., Azevedo E Silva, G., Chen, W.-Q., Eser, S., Engholm, G., Stiller, C. A., Monnereau, A., Woods, R. R., Visser, O., CONCORD Working Group. (2018). Global surveillance of trends in cancer survival 2000-14 (CONCORD-3): analysis of individual records for 37513025 patients diagnosed with one of 18 cancers from 322 population-based registries in 71 countries. Lancet (London, England), 391(10125), 1023-1075. https://doi.org/10.1016/S0140-6736(17)33326-3 
Brasil. (n.d.). Estimativas 2008: Incidência de Câncer no Brasil. Ministério Da Saúde. Secretaria de Atenção à Saúde. Instituto Nacional de Câncer. Coordenação de Prevenção e Vigilância de Câncer. http://bvsms.saude.gov.br/bvs/publicacoes/estimativa_incidencia_cancer_2008.pdf

Brasil. (2013). Atlas do Desenvolvimento Humano. Instituto de Pesquisa Econômica Aplicada (Brasil). Programa Das Nações Unidas Para o Desenvolvimento No Brasil. Fundação João Pinheiro. http://www.atlasbrasil.org.br/

Bray, F., Ferlay, J., Soerjomataram, I., Siegel, R. L., Torre, L. A., \& Jemal, A. (2018). Global cancer statistics 2018: GLOBOCAN estimates of incidence and mortality worldwide for 36 cancers in 185 countries. CA: A Cancer Journal for Clinicians, 68(6), 394-424. https://doi.org/10.3322/caac.21492

Camargo Jr., Kenneth R. de, \& Coeli, C. M. (2000). Reclink: aplicativo para o relacionamento de bases de dados, implementando o método probabilistic record linkage. Cadernos de Saúde Pública, 16(2), 439-447. https://doi.org/10.1590/S0102-311X2000000200014

Camargo Jr., Kenneth Rochel de, \& Coeli, C. M. (2015). Going open source: some lessons learned from the development of OpenRecLink. Cadernos de Saúde Pública, 31(2), 257-263. https://doi.org/10.1590/0102-311X00041214

Cancer Incidence in Five Continents. (1966). In R. Doll, P. M. Payne, \& J. A. H. Waterhouse (Eds.), Cancer Incidence in Five Continents (Vol I). Union Internationale Contre le Cancer. https://doi.org/10.1007/978-3-642-85849-9_1

Cheng, T.-Y. D., Cramb, S. M., Baade, P. D., Youlden, D. R., Nwogu, C., \& Reid, M. E. (2016). The International Epidemiology of Lung Cancer: Latest Trends, Disparities, and Tumor Characteristics. Journal of Thoracic Oncology: Official Publication of the International Association for the Study of Lung Cancer, 11(10), 1653-1671. https://doi.org/10.1016/j.jtho.2016.05.021

Chirlaque, M. D., Salmerón, D., Galceran, J., Ameijide, A., Mateos, A., Torrella, A., Jiménez, R., Larrañaga, N., Marcos-Gragera, R., Ardanaz, E., Sant, M., Minicozzi, P., Navarro, C., Sánchez, M. J., \& REDECAN Working Group. (2018). Cancer survival in adult patients in Spain. Results from nine populationbased cancer registries. Clinical \& Translational Oncology: Official Publication of the Federation of Spanish Oncology Societies and of the National Cancer Institute of Mexico, 20(2), 201-211. https://doi.org/10.1007/s12094-017-1710-6

Coutinho, E. S. F., \& Coeli, C. M. (2006). [Accuracy of the probabilistic record linkage methodology to ascertain deaths in survival studies]. Cadernos de Saude Publica, 22(10), 2249-2252. https://doi.org/10.1590/s0102-311x2006001000031

Dagenais, G. R., Leong, D. P., Rangarajan, S., Lanas, F., Lopez-Jaramillo, P., Gupta, R., Diaz, R., Avezum, A., Oliveira, G. B. F., Wielgosz, A., Parambath, S. R., Mony, P., Alhabib, K. F., Temizhan, A., Ismail, N., Chifamba, J., Yeates, K., Khatib, R., Rahman, O., \& Yusuf, S. (2019). Variations in common diseases, hospital admissions, and deaths in middle-aged adults in 21 countries from five continents (PURE): a prospective cohort study. Lancet (London, England). https://doi.org/10.1016/S0140-6736(19)32007-0

De Oliveira Mota, J., Boué, G., Guillou, S., Pierre, F., \& Membré, J.-M. (2019). Estimation of the burden of disease attributable to red meat consumption in France: Influence on colorectal cancer and cardiovascular diseases. Food and Chemical Toxicology, 130, 174-186. https://doi.org/10.1016/j.fct.2019.05.023

Dupont, W. D. (2009). Statistical Modeling for Biomedical Researchers. In Statistical Modeling for Biomedical Researchers (2nd ed). Cambridge University Press. https://doi.org/10.1017/cbo9780511575884

Ellis, L., Canchola, A. J., Spiegel, D., Ladabaum, U., Haile, R., \& Gomez, S. L. (2018). Trends in Cancer Survival by Health Insurance Status in California From 1997 to 2014. JAMA Oncology, 4(3), 317-323. https://doi.org/10.1001/jamaoncol.2017.3846

GBD Brazil Collaborators. (2018). Burden of disease in Brazil, 1990-2016: a systematic subnational analysis for the Global Burden of Disease Study 2016. Lancet (London, England), 392(10149), 760-775. https://doi.org/10.1016/S0140-6736(18)31221-2

GBD DALYs and HALE Collaborators. (2018). Global, regional, and national disability-adjusted life-years (DALYs) for 359 diseases and injuries and healthy life expectancy (HALE) for 195 countries and territories, 1990-2017: a systematic analysis for the Global Burden of Disease Study 2017. Lancet (London, England), 392(10159), 1859-1922. https://doi.org/10.1016/S0140-6736(18)32335-3

Global Burden of Disease Cancer Collaboration, Fitzmaurice, C., Abate, D., Abbasi, N., Abbastabar, H., Abd-Allah, F., Abdel-Rahman, O., Abdelalim, A., Abdoli, A., Abdollahpour, I., Abdulle, A. S. M., Abebe, N. D., Abraha, H. N., Abu-Raddad, L. J., Abualhasan, A., Adedeji, I. A., Advani, S. M., Afarideh, M., Afshari, M., \& Murray, C. J. L. (2019). Global, Regional, and National Cancer Incidence, Mortality, Years of Life Lost, Years Lived With Disability, and Disability-Adjusted Life-Years for 29 Cancer Groups, 1990 to 2017: A Systematic Analysis for the Global Burden of Disease Study. JAMA Oncology. https://doi.org/10.1001/jamaoncol.2019.2996

Global Burden of Disease Cancer Collaboration, Fitzmaurice, C., Akinyemiju, T. F., Al Lami, F. H., Alam, T., Alizadeh-Navaei, R., Allen, C., Alsharif, U., Alvis-Guzman, N., Amini, E., Anderson, B. O., Aremu, O., Artaman, A., Asgedom, S. W., Assadi, R., Atey, T. M., Avila-Burgos, L., Awasthi, A., Ba Saleem, H. O., \& Naghavi, M. (2018). Global, Regional, and National Cancer Incidence, Mortality, Years of Life Lost, Years Lived With Disability, and DisabilityAdjusted Life-Years for 29 Cancer Groups, 1990 to 2016: A Systematic Analysis for the Global Burden of Disease Study. JAMA Oncology, 4(11), 1553-1568. https://doi.org/10.1001/jamaoncol.2018.2706

Global Burden of Disease Cancer Collaboration, Fitzmaurice, C., Dicker, D., Pain, A., Hamavid, H., Moradi-Lakeh, M., MacIntyre, M. F., Allen, C., Hansen, G., Woodbrook, R., Wolfe, C., Hamadeh, R. R., Moore, A., Werdecker, A., Gessner, B. D., Te Ao, B., McMahon, B., Karimkhani, C., Yu, C., \& Naghavi, M. (2015). The Global Burden of Cancer 2013. JAMA Oncology, 1(4), 505-527. https://doi.org/10.1001/jamaoncol.2015.0735

Guerra, M. R., Bustamante-Teixeira, M. T., Corrêa, C. S. L., Abreu, D. M. X. de, Curado, M. P., Mooney, M., Naghavi, M., Teixeira, R., França, E. B., \& Malta, D. C. (2017). Magnitude and variation of the burden of cancer mortality in Brazil and Federation Units, 1990 and 2015. Revista Brasileira de Epidemiologia, 20 (Suppl 01), 102-115. https://doi.org/10.1590/1980-5497201700050009

India State-Level Disease Burden Initiative Cancer Collaborators. (2018). The burden of cancers and their variations across the states of India: the Global Burden of Disease Study 1990-2016. The Lancet. Oncology, 19(10), 1289-1306. https://doi.org/10.1016/S1470-2045(18)30447-9

Instituto Brasileiro de Geografia e Estatística. (2019). Estimativa população residente. https://www.ibge.gov.br/estatisticas/sociais/populacao.html 
Jerez-Roig, J., Souza, D. L. B., Medeiros, P. F. M., Barbosa, I. R., Curado, M. P., Costa, I. C. C., \& Lima, K. C. (2014). Future burden of prostate cancer mortality in Brazil: a population-based study. Cadernos de Saude Publica, 30(11), 2451-2458. https://doi.org/10.1590/0102-311x00007314

José, B. P. de S., Corrêa, R. de A., Malta, D. C., Passos, V. M. de A., França, E. B., Teixeira, R. A., \& Camargos, P. A. M. (2017). Mortality and disability from tobacco-related diseases in Brazil, 1990 to 2015. Rev Bras Epidemiol [Internet], 75-89. https://doi.org/10.1590/1980-5497201700050007

Llobera, J., Esteva, M., Rifà, J., Benito, E., Terrasa, J., Rojas, C., Pons, O., Catalán, G., \& Avellà, A. (2000). Terminal cancer, duration and prediction of survival time. European Journal of Cancer (Oxford, England: 1990), 36(16), 2036-2043. https://doi.org/10.1016/s0959-8049(00)00291-4

Ministério da Saúde. (2017). SIM-Sistema de Informações de Mortalidade. DATASUS. http://www2.datasus.gov.br/DATASUS/index.php?area=02

Ministério da Saúde (Brasil). Instituto Nacional de Câncer José Alencar Gomes da Silva (INCA). Coordenação-Geral de Prevenção e Vigilância. Divisão de Vigilância e Análise da Situação. (2012). Manual de rotinas e procedimentos para Registros de Câncer de Base Populacional (2a ed.), Inca. https://www.inca.gov.br/publicacoes/manuais/manual-de-rotinas-e-procedimentos-para-registros-de-cancer-de-base-populacional

Ministério da Saúde (Brasil). Instituto Nacional de Câncer José Alencar Gomes da Silva (INCA). (2019). Estatísticas de câncer. Causas e Prevenção. https://www.inca.gov.br/numeros-de-cancer

Murray, C. J., \& Lopes, A. D. (1996). Estimating causes of death: new methods and global and regional applications for 1990. In C. J. Murray \& A. D. Lopes (Eds.), The global burden of disease: a comprehensive assessment of mortality and disability from diseases, injuries, and risk factors in 1990 and projected to 2020 (pp. 117-200). Harvard School of Public Health on behalf of the World Health Organization and the World Bank. https://apps.who.int/iris/handle/10665/41864

Murray, C. J L. (1994). Quantifying the burden of disease: The technical basis for disability-adjusted life years. In Bulletin of the World Health Organization. 72(3): 429-445.

Murray, Christopher J L, \& Lopez, A. D. (2013). Measuring the global burden of disease. The New England Journal of Medicine, 369(5), 448-457. https://doi.org/10.1056/NEJMra1201534

Murray, Christopher J L, Vos, T., Lozano, R., Naghavi, M., Flaxman, A. D., Michaud, C., Ezzati, M., Shibuya, K., Salomon, J. A., Abdalla, S., Aboyans, V., Abraham, J., Ackerman, I., Aggarwal, R., Ahn, S. Y., Ali, M. K., Alvarado, M., Anderson, H. R., Anderson, L. M., \& Memish, Z. A. (2012). Disability-adjusted life years (DALYs) for 291 diseases and injuries in 21 regions, 1990-2010: a systematic analysis for the Global Burden of Disease Study 2010. Lancet (London, England), 380(9859), 2197-2223. https://doi.org/10.1016/S0140-6736(12)61689-4

Nikiforov, Y. E., Seethala, R. R., Tallini, G., Baloch, Z. W., Basolo, F., Thompson, L. D. R., Barletta, J. A., Wenig, B. M., Al Ghuzlan, A., Kakudo, K., Giordano, T. J., Alves, V. A., Khanafshar, E., Asa, S. L., El-Naggar, A. K., Gooding, W. E., Hodak, S. P., Lloyd, R. V, Maytal, G., \& Ghossein, R. A. (2016). Nomenclature Revision for Encapsulated Follicular Variant of Papillary Thyroid Carcinoma: A Paradigm Shift to Reduce Overtreatment of Indolent Tumors. JAMA Oncology, 2(8), 1023-1029. https://doi.org/10.1001/jamaoncol.2016.0386

Niu, X., Roche, L. M., Pawlish, K. S., \& Henry, K. A. (2013). Cancer survival disparities by health insurance status. Cancer Medicine, 2(3), 403-411. https://doi.org/10.1002/cam4.84

Organização Mundial da Saúde. (1997). CID-10 Classificação Estatística Internacional de Doenças e Problemas Relacionados à Saúde. 10a Rev. São Paulo: Universidade de São Paulo. http://www2.datasus.gov.br/DATASUS/index.php?area=060203

Parikh-Patel, A., Morris, C. R., \& Kizer, K. W. (2017). Disparities in quality of cancer care: The role of health insurance and population demographics. Medicine, 96(50), e9125. https://doi.org/10.1097/MD.0000000000009125

Pereira, R. E. (2011). Metodologia da determinação de prioridades no planeamento regional de saúde: uma proposta. Universidade Nova de Lisboa. https://run.unl.pt/handle/10362/9583

Santos, M. de O. (2018). Estimativa 2018: Incidência de Câncer no Brasil. Revista Brasileira de Cancerologia, 64(1), 119-120. https://doi.org/10.32635/21769745.RBC.2018v64n1.115

Soerjomataram, I., Lortet-Tieulent, J., Ferlay, J., Forman, D., Mathers, C., Parkin, D. M., \& Bray, F. (2012). Estimating and validating disability-adjusted life years at the global level: a methodological framework for cancer. BMC Medical Research Methodology, 12, 125. https://doi.org/10.1186/1471-2288-12-125

Soerjomataram, I., Lortet-Tieulent, J., Parkin, D. M., Ferlay, J., Mathers, C., Forman, D., \& Bray, F. (2012). Global burden of cancer in 2008: a systematic analysis of disability-adjusted life-years in 12 world regions. Lancet, 380(9856), 1840-1850. https://doi.org/10.1016/S0140-6736(12)60919-2

Stewart, B. W., \& Wild, C. P. (2014). World cancer report 2014. In World Health Organization. International Agency for Research on Cancer. https://www.who.int/cancer/publications/WRC_2014/en/

Strasser-Weippl, K., Chavarri-Guerra, Y., Villarreal-Garza, C., Bychkovsky, B. L., Debiasi, M., Liedke, P. E. R., Soto-Perez-de-Celis, E., Dizon, D., Cazap, E., de Lima Lopes, G., Touya, D., Nunes, J. S., St Louis, J., Vail, C., Bukowski, A., Ramos-Elias, P., Unger-Saldaña, K., Brandao, D. F., Ferreyra, M. E., \& Goss, P. E. (2015). Progress and remaining challenges for cancer control in Latin America and the Caribbean. The Lancet. Oncology, 16(14), 1405-1438. https://doi.org/10.1016/S1470-2045(15)00218-1

Teixeira, C. F. (2010). Planejamento em saúde: conceitos, métodos e experiências. EDUFBA.

Tervonen, H. E., Aranda, S., Roder, D., You, H., Walton, R., Morrell, S., Baker, D., \& Currow, D. C. (2017). Cancer survival disparities worsening by socioeconomic disadvantage over the last 3 decades in new South Wales, Australia. BMC Public Health, 17(1), 691. https://doi.org/10.1186/s12889-017-4692-y

Tourinho-Barbosa, R. R., Pompeo, A. C. L., \& Glina, S. (n.d.). Prostate cancer in Brazil and Latin America: epidemiology and screening. International Braz $j$ Urol: Official Journal of the Brazilian Society of Urology, 42(6), 1081-1090. https://doi.org/10.1590/S1677-5538.IBJU.2015.0690 
Research, Society and Development, v. 10, n. 5, e40210515140, 2021

(CC BY 4.0) | ISSN 2525-3409 | DOI: http://dx.doi.org/10.33448/rsd-v10i5.15140

Traebert, J., Schneider, I. J. C., Colussi, C. F. C. F., \& de Lacerda, J. T. (2013). Burden of disease due to cancer in a Southern Brazilian state. Cancer Epidemiology, 37(6), 788-792. https://doi.org/10.1016/j.canep.2013.08.007

Zeng, C., Wen, W., Morgans, A. K., Pao, W., Shu, X.-O., \& Zheng, W. (2015). Disparities by Race, Age, and Sex in the Improvement of Survival for Major Cancers: Results From the National Cancer Institute Surveillance, Epidemiology, and End Results (SEER) Program in the United States, 1990 to 2010 . JAMA Oncology, 1(1), 88-96. https://doi.org/10.1001/jamaoncol.2014.161 